\title{
IMPLEMENTASI SISTEM KENDALI VARIABLE SPEED DRIVE PADA INVERTER 3 FASA MENGGUNAKAN MIKROKONTROL AT89S52
}

\author{
Emmanuel Agung Nugroho \\ Program Studi Teknik Mekatronika \\ Politeknik Enjinering Indorama \\ Email: lekagung@yahoo.com
}

\begin{abstract}
ABSTRAK
Penelitian ini mengimplementasikan perancangan sistem kendali Variable Speed Drive (VSD) pada Inverter 3 fasa yang dilakukan dengan software Power Simulator kedalam IC terprogram mikrokontrol tipe AT89S52. IC mikrokontrol AT89S52 akan dibangkitkan sinyal sinusoidal 3 fasa sebagai sinyal referensi pada inverter 3 fasa yang digunakan untuk mengendalikan motor induksi 3 fasa dengan metode Sinusoidal Pulse Width Modulation (SPWM). Metode pembangkitan sinyal 3 fasa didalam mikrokontroler AT89S52 ini dilakukan dengan cara look up table yaitu pengambilan data sampling dikrit 256 data dari software power simulator kedalam port input. Pada setiap port keluaran mikrokontroler membentuk satu pola quantisasi sinyal gelombang satu fasa, untuk membangkitkan gelombang 3 fasa dilakukan dengan mengalamatkan data keluaran pada ketiga port keluaran. Dengan menggunakan Digital to Analog Converter (DAC) maka pola quantisasi yang dihasilkan oleh setiap port mikrokontroler diubah menjadi sinyal analog berbentuk sinusoidal. Rangkaian multiplier pada sistem ini digunakan untuk menghasilkan sinyal sinusoidal yang dapat diatur frekuensi dan amplitudonya secara bersama-sama. Data pengujian menunjukkan perubahan tegangan dan frekuensi dengan rasio $1: 5,2$ dan perbandingan tegangan fasa netral dengan tegangan keluaran antar fasa menunjukkan nilai perbandingan $1: 1,733$ atau $1: \sqrt{3}$.
\end{abstract}

Kata kunci: variable speed drive, sinusoidal pulse width modulation, look up table, digital to analog converter, multiplier.

\begin{abstract}
This research implements the design of Variable Speed Driver (VSD) control system in three phase inverter which is done by using Power Simulator software and implement to microcontrol AT89S52. The microcontrol AT89S52 will generate three phase sinusoidal signal as reference signal for three phase inverter which is used to control three phase induction motor with Sinusoidal Pulse Width Modulation (SPWM) method. To generate the three phase sinusoidal signal from microcontrol AT89S52 is done by look up table methode that is taking 256 discrit data sampling into microcontroler AT89S52 port input. On the output side for each port can form a single phase waveform with quantization pattern, so there are need three ports to produce the three phase signals. By using Digital to Analog Converter will change the three phase quantizier signal to smooth sinusidal signal. The multiplier circuit in this system is used to generate sinusoidal signals that can be regulated frequency and amplitude together. The result data shows voltages and frequencys with a ratio of $1: 5,2$ and also showing a neutral-phase output voltage ratio with a phase to phase output voltagewith a ratio $1: 1,733$ atau $1: \sqrt{3}$.
\end{abstract}

Keywords: variable speed drive, sinusoidal pulse width modulation, look up table, digital to analog converter, multiplier.

\section{PENDAHULUAN}

Penggunaan motor induksi di industri semakin banyak mengingat kesederhanaan konstruksi, keamanan terhadap lingkungan dan kemudahan perawatannya jika dibandingkan dengan motor DC. Kelebihan motor DC adalah kemudahan metode pengendalaiannya yang memungkinkan pengaturan kecepatan dan juga torsi secara bersamaan dimana hal tersebut selama ini belum bisa dilakukan bila menggunakan motor induksi. Berkembangnya teknologi semikonduktor maka dewasa ini mendorong berkembangnya peralatan pengatur kecepatan motor induksi dengan menggunakan inverter yang biasa disebut Variable Speed Drive (VSD) tetapi karena metode pengendaliannya dilakukan dengan mengatur tegangan dan frekuensi secara bersamaan maka devais semacam ini disebut Variable Voltage Variable Frequency (VVVF) atau Volt/Hertz Inverter. Metode ini bertujuan untuk mengendalikan kecepatan motor 
induksi dan torsi motor yang bisa dikendalikan secara bersamaan. Berkembangnya peralatan ini memberikan tambahan keuntungan penggunaan motor induksi yaitu penggunaan motor menjadi lebih efisien, peningkatan fleksibilitas produksi dan peningkatan usia pemakaian motor induksi karena tidak selalu digunakan pada kecepatan nominalnya[1].

\subsection{Motor Induksi 3 Fasa}

Motor induksi adalah motor yang bekerja berdasarkan prinsip induksi medan magnet dari kumparan stator yang menggerakkan rotor sehingga berputar sesuai hukum lorentz. Motor induksi disebut juga dengan motor asinkron karena kecepatan putar rotor tidak pernah sama dengan kecepatan sinkron yang dihasilkan oleh medan stator yang disebut dengan slip. Persamaan 1 menyatakan kecepatan sikron medan stator yang dimiliki oleh motor induksi 3 fasa yaitu:

$$
N s=\frac{120 f}{P}(\mathrm{rpm})
$$

Dengan Ns adalah kecepatan sinkron; f adalah frekuensi sumber dan P adalah jumlah kutub. Setiap motor induksi dipersiapkan untuk memiliki kemampuan mengangkat beban yang disebut dengan torka. Torka elektromagnetik motor induksi didefinisikan dengan persamaan 2.

$$
T_{e}=\left(\frac{3 P}{2}\right)\left(\frac{E}{\omega}\right)^{2} \frac{R_{r}+\omega_{s 1}}{R_{r}^{2}+\left[\omega_{s 1} L_{1 r}\right]^{2}}
$$

dengan Te adalah torka elektromagnetik motor; P adalah jumlah kutub, E adalah gaya gerak elektrik pada rotor; $\omega_{s 1}=\omega-\omega r$ adalah frekuensi slip rotor, dengan $\omega$ dan $\omega_{\mathrm{r}}$ masing-masing adalah frekuensi sudut stator dan frekuensi sudut rotor, $\mathrm{Rr}$ adalah resistansi rotor dan $\mathrm{Lr}$ adalah induktansi bocor rotor [2][3][4].

Memperhatikan persamaan (2), karakteristik torka terhadap putaran dan hubungan tegangan sumber (Va) dengan gaya gerak elektrik E pada rangkaian pengganti motor induksi pada Gambar 1, maka pengendalian motor induksi dapat dilakukan dengan cara mengubah tegangan sumber Va.

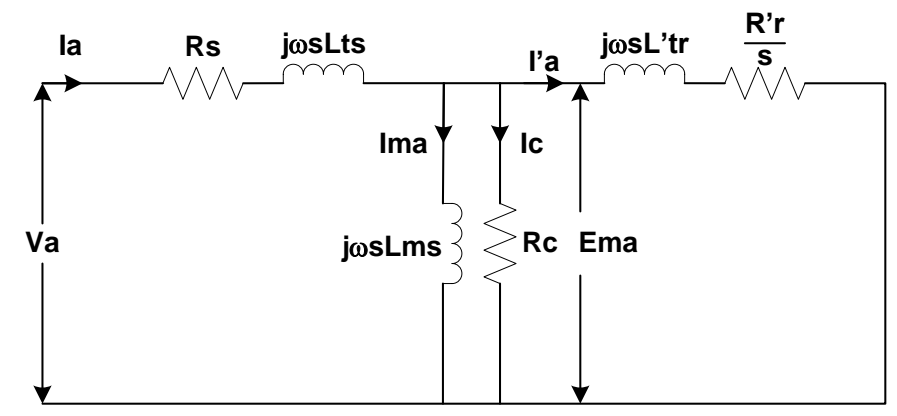

Gambar 1. Rangkaian Ekivalen Satu Fase Motor Induksi Tiga Fase[2][3][4]

Berdasar Gambar 1 dapat dihitung daya mekanis motor menggunakan persamaan 3.

$$
P_{m e k}=\frac{3(1-s)}{s} R_{r}^{\prime}\left(I_{a}^{\prime}\right)^{2} \text { (watt) }
$$

Torsi yang dihasilkan dinyatakan dengan persamaan 4 .

$$
T=\frac{P_{m e k}}{\omega_{m}}(\mathrm{Nm})
$$

$\mathrm{s}:$ slip motor, $\omega_{\mathrm{m}}$ : kecepatan sudut mekanis rotor sebesar : $\frac{2 \pi \mathrm{N}}{60}$

\subsection{Variable Speed Drive}

Kecenderungan yang terjadi pada peralatan pengaturan kecepatan motor induksi mengakibatkan turunnya torsi motor induksi tersebut pada saat kecepatan rendah. Variable Speed Drive (VSD) adalah suatu peralatan pengendali motor induksi 3 fasa dengan prinsip mengatur besaran frekuensi dan tegangan 
yang diterima oleh motor induksi. Pengaturan frekuensi dan tegangan secara bersamaan ini mengakibatkan kecepatan berubah dengan tetap menjaga torsi pada nilai konstan.

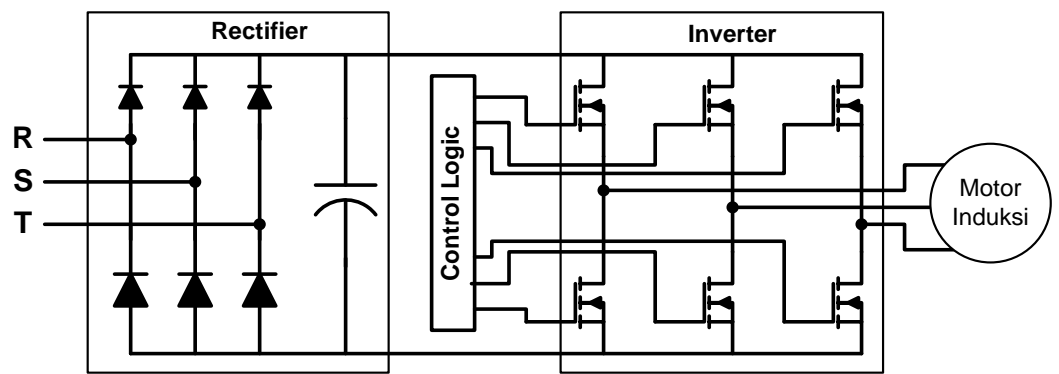

Gambar 2. Diagram Variable Speed Drivers[5]

Gambar 2 menunjukkan bagian-bagian dari Variable Speed Drive Inverter yang memiliki prinsip kerja sebagai berikut:

a. Tegangan listrik 3 fasa dari sumber disearahkan dengan rangkaian peenyearah 3 fasa three Phase rectifier sehingga menghasilkan tegangan DC murni setelah melalui DC bus kapasitor.

b. Tegangan DC tersebut digunakan sebagai sumber yang dialirkan menuju inverter melalui saklarsaklar daya 3 lengan yang sudah dikendalikan dengan control logic sehingga pada setiap saklar yang berada dalam satu lengan bekerja secara bergantian dan dengan saklar pada lengan yang lain saling bergeser $120^{\circ}$.

c. Saklar daya berupa Insulated Gate Bipolar Transistor (IGBT) yaitu suatu devais saklar semikonduktor yang mampu bekerja pada frekuensi relatif tinggi dengan kemampuan melewatkan arus yang relatif besar jika dibandingkan dengan mosfet dan transistor biasa.

\subsection{Sinusoidal Pulse Width Modulation (SPWM)}

Sinusoidal Pulse Width Modulation (SPWM) atau modulasi lebar pulsa adalah satu teknik pembangkitan pulsa digital melalui proses pembandingan sinyal referensi dengan sinyal carrier. Pulsa yang dihasilkan melalui teknik modulasi lebar pulsa digunakan untuk memicu saklar daya IGBT sehingga mampu melakukan pencacahan secara terstruktur terhadap tegangan DC masukan pada inverter 3 fasa tersebut. Prinsip kerja sinyal SPWM adalah berdasar perbandingan sinyal referensi dan sinyal carrier sehingga menghasilkan pulsa dengan metode seperti ditunjukkan pada Gambar 3 berikut:

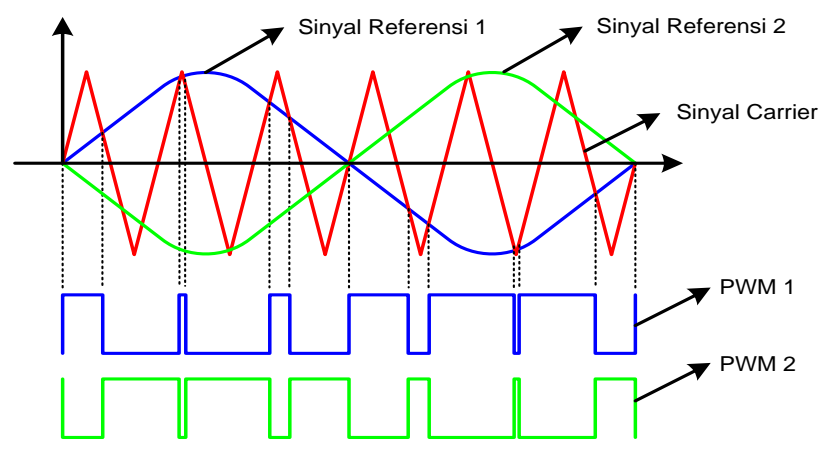

Gambar 3. Teknik Modulasi Lebar Pulsa Dengan Referensi Gelombang Sinus[5]

Dari Gambar 3 dapat dijelaskan mekanisme pembangkitan pulsa PWM sebagai berikut:

a. Sinyal PWM 1 diperoleh dengan membandingkan sinyal referensi 1 sinus dan sinyal pembawa segitiga dinyatakan dengan persamaan 5 dan 6 .

$$
\begin{aligned}
\mathrm{PWM}_{1} & =\left\{\begin{array}{l}
1, \text { jika } A_{r} \cdot \sin (\omega t) \geq A_{c} \cdot \operatorname{sgt}(\omega t) \\
0, \text { lainnya }
\end{array}\right. \\
\text { atau } & \\
\mathrm{PWM}_{1} & =\left\{\begin{array}{l}
1, \text { jika M.sin }(\omega t) \geq \operatorname{sgt}(\omega t) \\
0, \text { lainnya }
\end{array}\right.
\end{aligned}
$$

b. Sinyal PWM2 diperoleh dengan membandingkan sinyal referensi $-\sin (\omega t)$ dan sinyal pembawa segitiga $(\operatorname{sgt}(\omega t))$ dinyatakan pada persamaan 7 dan 8 . 


$$
\begin{aligned}
& \mathrm{PWM}_{2}=\left\{\begin{array}{l}
1, \text { jika } A_{r} \cdot-\sin (\omega t) \geq A_{c} \cdot \operatorname{sgt}(\omega t) \\
0, \text { lainnya }
\end{array}\right. \\
& \text { atau } \\
& \mathrm{PWM}_{2}=\left\{\begin{array}{l}
1, \text { jika M. }-\sin (\omega \mathrm{t}) \geq \operatorname{sgt}(\omega \mathrm{t}) \\
0, \text { lainnya }
\end{array}\right.
\end{aligned}
$$

\section{METODE PENELITIAN}

Garis besar perancangan sistem pengendalian variable speed drive dengan menggunakan mikrokontrol AT89S52 ditunjukkan seperti pada gambar 4 berikut:

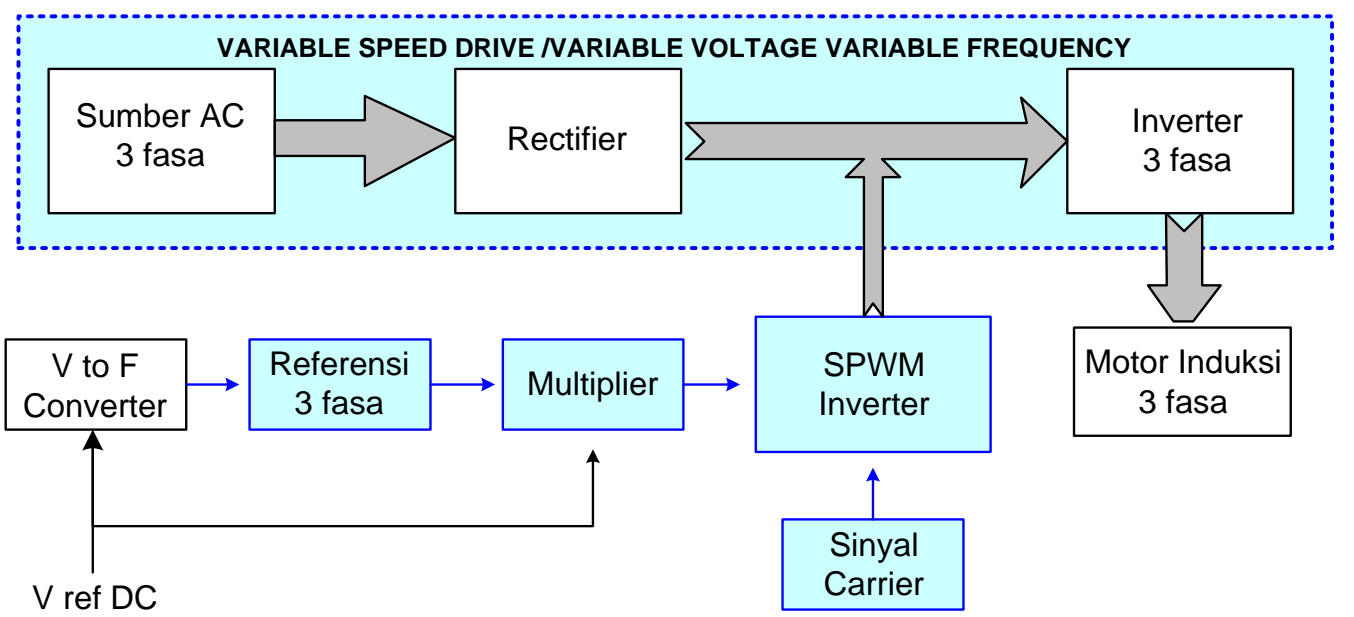

Gambar 4. Diagram Blok Perancangan Sistem Kendali Variable Speed Drive

Pada Gambar 4 menunjukkan diagram blok perancangan sistem pengendalian Variable Speed Drive secara lengkap.

\subsection{To F Convereter}

V to F konverter merupakan IC LM 331 yang mengubah tegangan DC referensi menjadi pulsa digital dengan frekuensi yang berubah secara linier mengikuti perubahan tegangan referensi. Pulsa digital yang dihasilkan oleh LM 331 dimasukkan kedalam IC counter 8 bit 4520, dan digunakan sebagai data informasi pada port input mikrokontroler AT89S52.

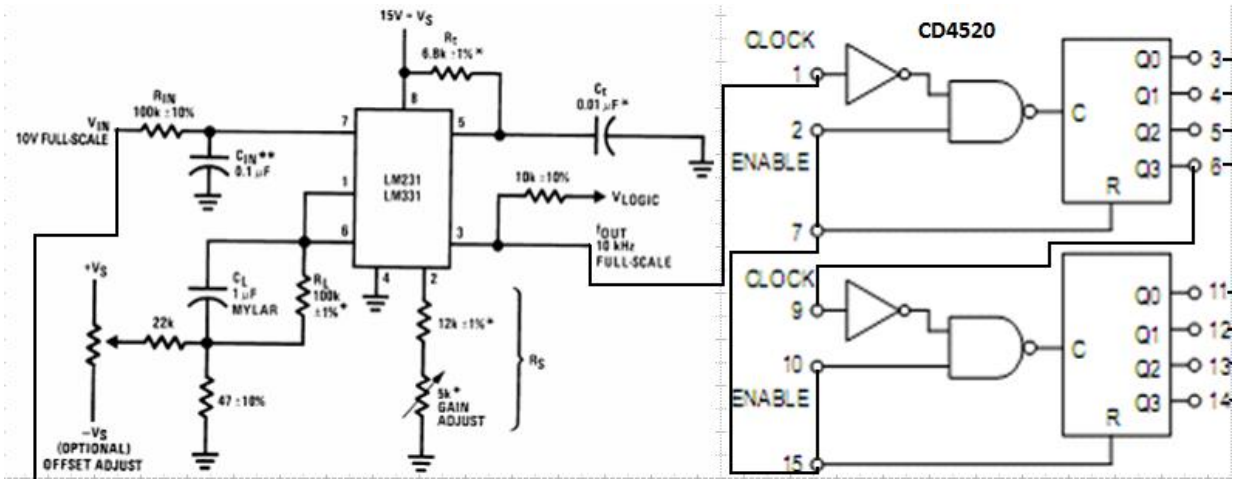

Gambar 5. Rangkaian Volt/ Hertz Dengan IC LM 331 Dan IC 4520 [6]

Pada Gambar 5 menunjukkan IC LM 331 sebagai converter V to Hertz yang disambung langsung dengan IC conter 4520 sehingga menghasilkan 8 karakteristik pulsa sebagai informasi port input pada mikrokontroller AT89S52. Frekuensi yang dihasilkan oleh LM 331 dinyatakan dengan persamaan 9.

$$
f_{\text {out }}=\frac{V_{\text {in }}}{2.09} \times \frac{R s}{R l} \times \frac{1}{R_{\tau} \cdot C_{\tau}}
$$




\subsection{Pembentukan Sinyal Referensi 3 Fasa}

Sinyal referensi berupa sinyal sinusoidal 3 fasa yang masing-masing tergeser $120^{\circ}$. Proses pembentukan gelombang ini dilakukan dengan memasukkan data secara look up table dari suatu rangkaian simulasi dengan Power Simulator yang menghasilkan gelombang sinusoida 3 fasa. Metode look up table adalah suatu metode pemrograman dengan mengambil data-data sampling dan memasukkannya kedalam mikrokontroler untuk membentuk suatu gelombang keluaran. Metode penyambungan sinyal informasi dan pengalamatan data keluaran mikrokontroler AT89S52 ditunjukkan pada Gambar 6:

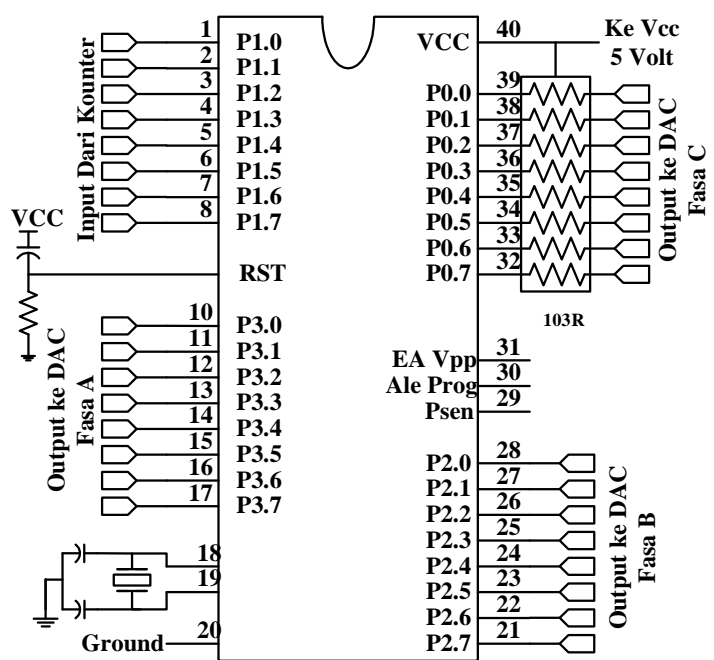

\section{Gambar 6. Mikrokontrol AT89S52 Sebagai Pembangkit Sinyal Referensi [7]}

Pada Gambar 6 menjelaskan setiap port mikrokontroller jenis AT89S52 memiliki 8 bit data maka jumlah bit maksimal dalam satu kelompok port adalah $2^{8}(256)$ data, untuk itu data sampling yang diambil dalam proses pengisian data secara look up table untuk dimasukkan kedalam mikrokontroller maksimal 256 data. Sedangkan untuk menghasilkan sinyal 3 fasa dilakukan pemrograman arimatik yang bertujuan menciptakan dua buah sinyal lainya yang saling tergeser $120^{\circ}$ dari sinyal pertama.

Sinyal Sinyal 3 fasa yang dihasilkan oleh mikrokontroller juga masih berbentuk nilai-nilai diskret yang harus diubah kembali menjadi sinyal analog. Untuk itu diperlukan konverter Digital to Analog yang menterjemahkan sinyal diskret tersebut menjadi sinyal analog. Untuk realisasi ini keluaran mikrokontroller terkoneksi dengan rangkaian DAC 0808 yang terkombinasi dengan beberapa rangkaian penguat seperti pada Gambar 7 .

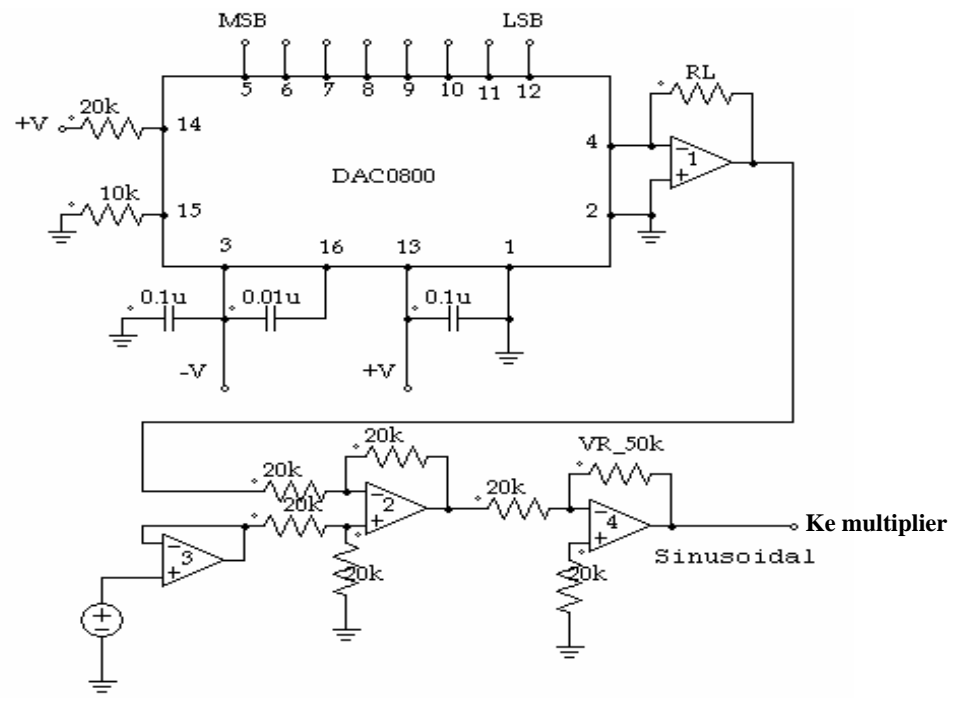

Gambar 7. Sistem Konversi Digital To Analog Dengan DAC 0808[8] 
Dengan menggunakan rangkaian seperti pada Gambar 7 maka pada terminal outputnya menghasilkan gelombang sinus murni. Sistem ini adalah sistem 3 fasa sehingga dibuat 3 buah rangkaian DAC seperti gambar 7 untuk mengolah 3 buah gelombang sinus bergeser $120^{\circ}$.

Sistem Variable Speed Drive adalah sistem pengaturan tegangan dan frekuensi keluaran inverter secara bersamaan sehingga diperlukan multiplying methode sebagai rangkaian pengolah dengan memanfaatkan sinyal inputan berupa gelombang sinusoidal yang dihasilkan oleh DAC dengan tegangan DC yang dihasilkan dari resistor variable pada input DC. Rangkaian multiplying methode ditunjukkan pada Gambar 8 :

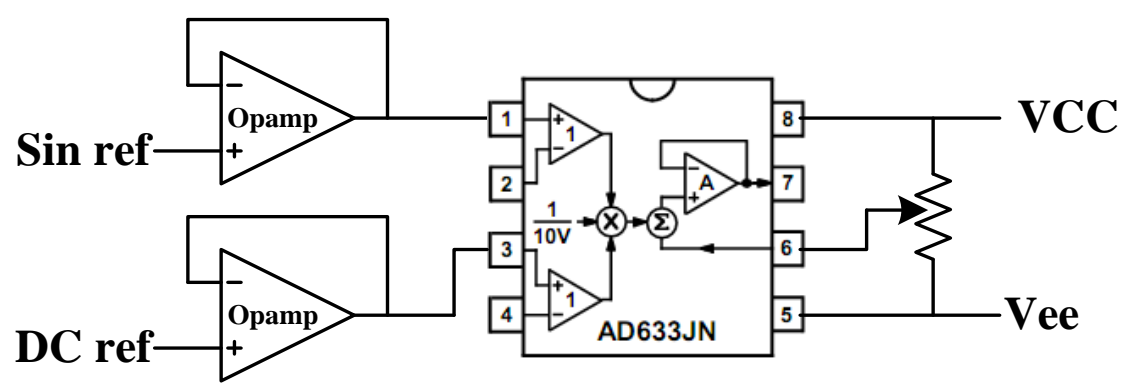

Gambar 8. Rangkaian Multiplyer AD 633[8]

Dengan rangkaian seperti pada Gambar 8 maka Frekuensi gelombang sinusoidal menjadi berubah jika tegangan refrensi pada rangkaian $\mathrm{V}$ to $\mathrm{F}$ tersebut juga berubah. Sehingga sinyal keluaran rangkaian pengali AD 633 mengalami dua bentuk perubahan seiring berubahnya tegangan DC referensi rangkaian V to F konverter, yaitu perubahan amplitudo sekaligus perubahan frekuensinya. Jadi pada multiplier ini menghasilkan sebuah sinyal sinusoidal yang frekuensi dan amplitudonya terkendali oleh perubahan kedua sinyal masukannya.

\subsection{Pembentukan Sinyal Carrier}

Sinyal carrier yang dibutuhkan adalah gelombang segitiga dengan frekuensi 5000 Hertz yang dibentuk dari rangkaian XR 2206. IC XR-2206 merupakan sebuah IC generator monolitik yang didesain untuk membangkitkan gelombang segitiga. Gelombang keluaran dari IC ini dapat diubah antara amplituda dan frekuensinya tergantung dari tegangan dan pengaturan komponen pembangkit frekuensi pendukung sistem monolitik ini. Frekuensi yang dapat dihasilkan dapat dipilih antara $0,01 \mathrm{~Hz}$ sampai lebih dari $1 \mathrm{MHz}$, disesuaikan dengan range yang ada. Gambar 9 merupakan bentuk rangkaian dari pembangkit gelombang segitiga dengan menggunakan IC XR-2206.

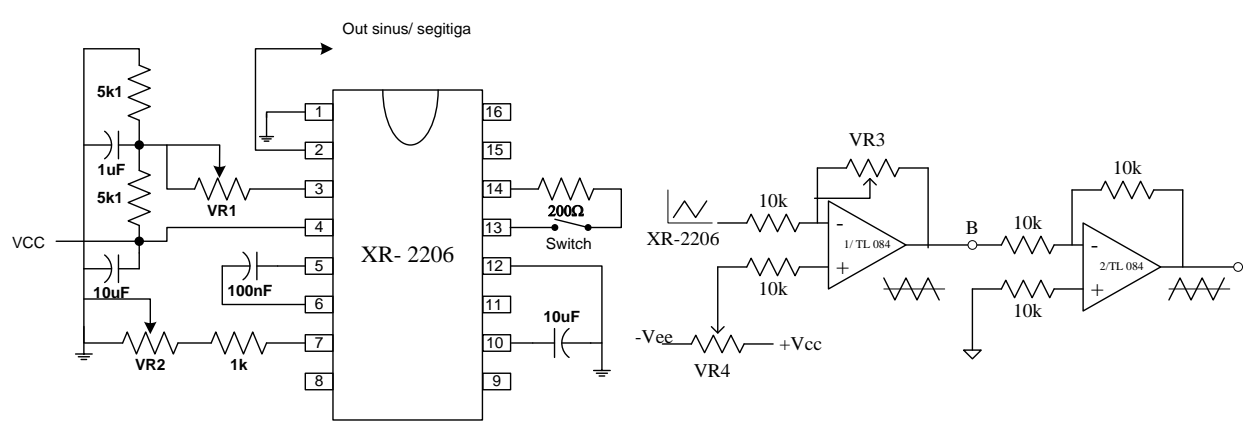

Gambar 9. Rangkaian XR-2206 Sebagai Pembangkit Gelombang Segitiga [9]

Dari rangkaian pada Gambar 9 dijelaskan bahwa pembentukan gelombang segitiga ditentukan oleh switch pada pin 13 yang terhubung dengan resistor $200 \Omega$ pada pin 14, jika saklar dalam kondisi open maka gelombang yang dihasilkan berupa gelombang segitiga. Terjadinya frekuensi ditentukan oleh nilai kapasitor pada pin 5 dan 6 yang dikombinasi dengan pengaturan resistor VR2 pada pin 7 . Sedangkan VR1 berfungsi untuk mengatur amplitudo gelombang yang dihasilkan. Rangkaian Op-Amp dengan kombinasi penguat inverting diperlukan untuk menghasilkan gelombang segitiga yang bisa diatur posisi dan amplitudonya secara lebih maksimal. 


\subsection{Rangkaian Driver}

Rangkaian driver adalah rangkaian penghubung antara rangkaian kontrol dengan rangkaian daya, rangkaian driver pada sistem inverter 3 fasa ini berfungsi memindahkan sinyal PWM yang dihasilkan dari modulasi gelombang sinus 3 fasa $50 \mathrm{~Hz}$, dengan sebuah sinyal carrier gelombang segitiga $5000 \mathrm{~Hz}$ kedalam rangkaian daya inverter yang terdiri dari 6 buah saklar elektronik. Rangkaian driver pada perancangan inverter ini ditunjukkan pada Gambar 10.

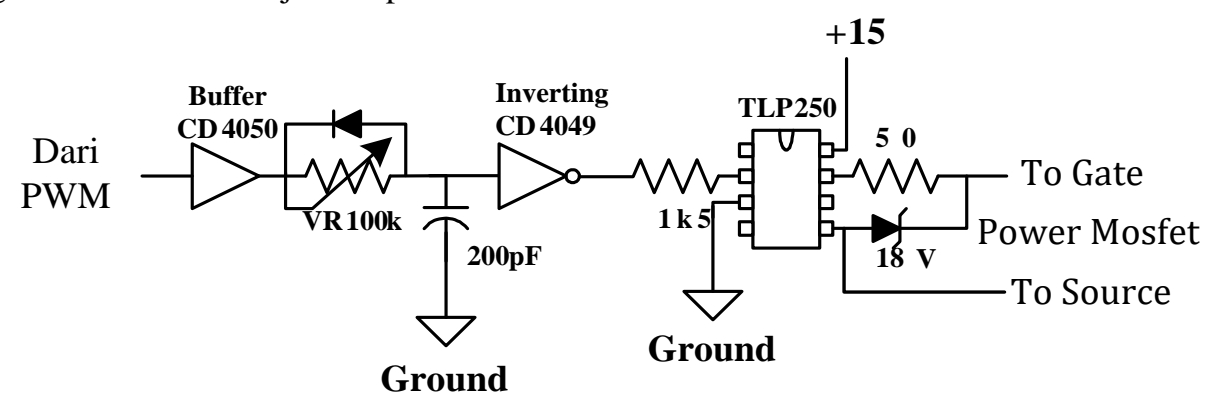

Gambar 10. Rangkaian Driver Dengan Deadtime[8]

Pada Gambar 10 menunjukkan sebuah rangkaian driver dari sebuah input PWM yang pada sisi outputnya memicu Gate IGBT. Pada perancangan ini driver yang digunakan adalah TLP 250 yang compatible dengan frekeunsi kerja IGBT yang digunakan. Pada output TLP 250 yang terhubung dengan gate IGBT dipasang dioda zener 1Watt /18 Volt yang berfungsi sebagai blocking apabila terjadi kebocoran tegangan pada rangkaian daya inverter sehingga rangkaian driver tetap terlindungi [9].

\subsection{Inverter 3 Fasa}

Rangkaian daya inverter tiga fasa tiga lengan (three-leg inverter) yang memiliki enam buah saklar dan sumber tegangan DC. Suatu converter DC to AC jenis sumber tegangan (voltage-type inverter) harus memenuhi dua syarat, yaitu saklar yang terletak pada satu lengan tidak boleh konduksi secara bersamaan hingga menimbulkan arus hubung singkat, dan arus sisi AC harus selalu dijaga kontinuitasnya. Mengacu pada kedua syarat tersebut maka akan terdapat $2^{3}$ kondisi (delapan kondisi saklar) seperti ditunjukan pada Gambar 11 berikut.

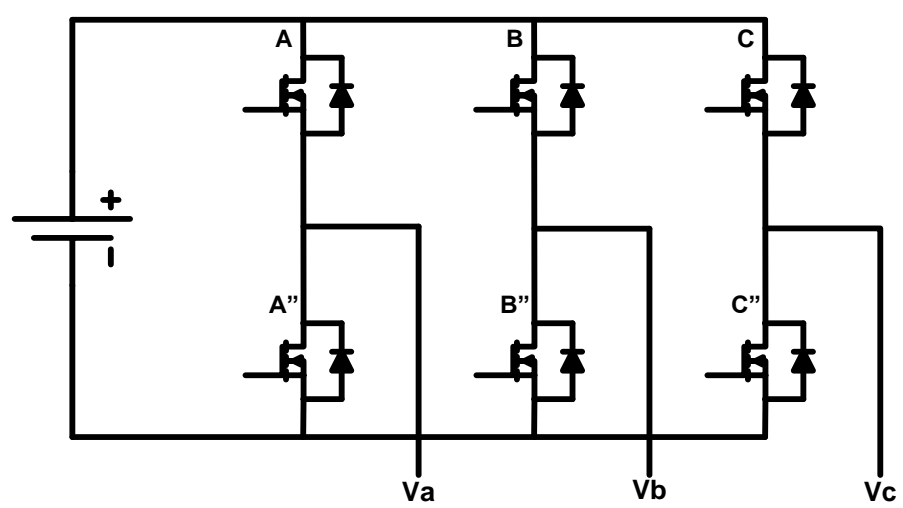

Gambar 11. Konfigurasi Inverter 3 Fasa 3 Lengan[5][8]

Gambar 11 menunjukkan konfigurasi inverter 3 fasa 3 lengan dibentuk oleh 6 buah saklar daya dengan masing-masing dua saklar berpasangan untuk menghasilkan setiap fasa untuk setiap lengannya. Lengan "a" dibentuk oleh saklar A pada sisi positif dan saklar A' pada sisi negatif yang bekerja secara bergantian demikian pula dengan saklar "b" dan "c". Dengan teknik kendali SPWM maka konfigurasi saklar daya inverter diatas dapat menghasilkan beberapa kemungkinan pensaklaran seperti pada Gambar 12 berikut. 


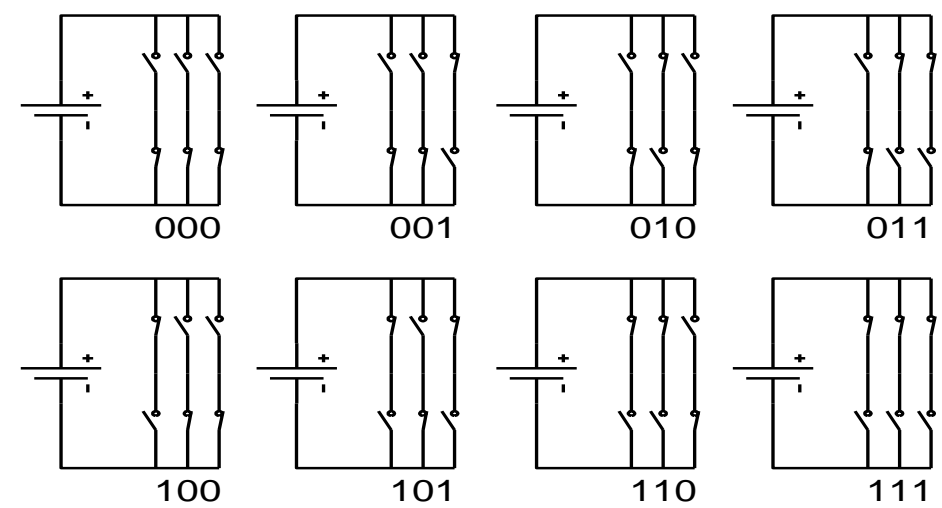

Gambar 12. Konfigurasi Saklar Daya Inverter 3 Fasa 3 Lengan[8]

Dari konfigurasi pensaklaran pada Gambar 12 maka dapat diturunkan suatu persamaan tegangan antar fasa sebagaimana pada persamaan 10 .

$\left[\begin{array}{l}V_{a b} \\ V_{b c} \\ V_{c a}\end{array}\right]=V_{d c}\left[\begin{array}{lrr}1 & -1 & 0 \\ 0 & 1 & -1 \\ -1 & 0 & 1\end{array}\right]\left[\begin{array}{l}a \\ b \\ c\end{array}\right]$

Sedangkan tegangan fasa yang dihasilkan oleh inverter diatas dinyatakan pada persamaan 11.

$\left[\begin{array}{l}V_{a} \\ V_{b} \\ V_{c}\end{array}\right]=\frac{1}{3} V_{d c}\left[\begin{array}{rrr}2 & -1 & -1 \\ -1 & 2 & -1 \\ -1 & -1 & 1\end{array}\right]\left[\begin{array}{l}a \\ b \\ c\end{array}\right]$

Sehingga dari kedua persamaan diatas dapat dibuat suatu tabel nilai tegangan keluaran inverter sebagai berikut :

Tabel 1. Nilai tegangan keluaran inverter 3 fasa

\begin{tabular}{ccccccccc}
\hline $\boldsymbol{S} \boldsymbol{a}$ & $\boldsymbol{S} \boldsymbol{b}$ & $\boldsymbol{S} \boldsymbol{c}$ & $\boldsymbol{V} \boldsymbol{a}-\boldsymbol{n}$ & $\boldsymbol{V} \boldsymbol{b}-\boldsymbol{n}$ & $\boldsymbol{V} \boldsymbol{c}-\boldsymbol{n}$ & $\boldsymbol{V} \boldsymbol{a}-\boldsymbol{b}$ & $\boldsymbol{V} \boldsymbol{b}-\boldsymbol{c}$ & $\boldsymbol{V} \boldsymbol{c}-\boldsymbol{a}$ \\
\hline 0 & 0 & 0 & 0 & 0 & 0 & 0 & 0 & 0 \\
0 & 0 & 1 & $-\mathrm{V}_{\mathrm{dc} / 3}$ & $-\mathrm{V}_{\mathrm{dc} / 3}$ & $2 \mathrm{~V}_{\mathrm{dc} / 3}$ & 0 & $-\mathrm{V}_{\mathrm{dc}}$ & $\mathrm{V}_{\mathrm{dc}}$ \\
0 & 1 & 0 & $-\mathrm{V}_{\mathrm{dc} / 3}$ & $2 \mathrm{~V}_{\mathrm{dc} / 3}$ & $-\mathrm{V}_{\mathrm{dc} / 3}$ & $-\mathrm{V}_{\mathrm{dc}}$ & $\mathrm{V}_{\mathrm{dc}}$ & 0 \\
0 & 1 & 1 & $-2 \mathrm{~V}_{\mathrm{dc} / 3}$ & $\mathrm{~V}_{\mathrm{dc} / 3}$ & $\mathrm{~V}_{\mathrm{dc} / 3}$ & $-\mathrm{V}_{\mathrm{dc}}$ & 0 & $\mathrm{~V}_{\mathrm{dc}}$ \\
1 & 0 & 0 & $2 \mathrm{~V}_{\mathrm{dc} / 3}$ & $-\mathrm{V}_{\mathrm{dc} / 3}$ & $-\mathrm{V}_{\mathrm{dc} / 3}$ & $\mathrm{~V}_{\mathrm{dc}}$ & 0 & $-\mathrm{V}_{\mathrm{dc}}$ \\
1 & 0 & 1 & $\mathrm{~V}_{\mathrm{dc} / 3}$ & $-2 \mathrm{~V}_{\mathrm{dc} / 3}$ & $\mathrm{~V}_{\mathrm{dc} / 3}$ & $\mathrm{~V}_{\mathrm{dc}}$ & $-\mathrm{V}_{\mathrm{dc}}$ & 0 \\
1 & 1 & 0 & $\mathrm{~V}_{\mathrm{dc} / 3}$ & $\mathrm{~V}_{\mathrm{dc} / 3}$ & $-2 \mathrm{~V}_{\mathrm{dc} / 3}$ & 0 & $\mathrm{~V}_{\mathrm{dc}}$ & $-\mathrm{V}_{\mathrm{dc}}$ \\
1 & 1 & 1 & 0 & 0 & 0 & 0 & 0 & 0 \\
\hline
\end{tabular}

Tabel 1. Menjelaskan metode penyaklaran saklar daya Inverter 3 fasa dan tegangan keluaran yang dihasilkan inverter 3 fasa 3 lengan.

\section{HASIL DAN PEMBAHASAN}

\subsection{Pengujian Rangkaian Kontrol}

Jenis Variable Speed Drive dalam penelitian ini adalah model Variable Voltage Variable Frequensi (VVVF) sehingga setiap tegangan kerja inverter berubah, maka frekuensi kerja inverter juga berubah. Data pengujian perubahan tegangan dan frekuensi pada rangkaian $\mathrm{V}$ to $\mathrm{F}$ dalam bentuk grafik konversi ditunjukkan pada gambar 13. 


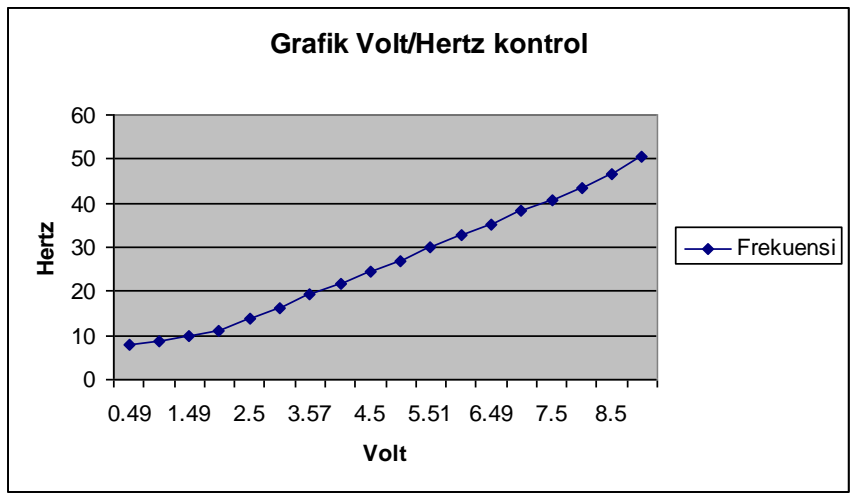

Gambar 13. Grafik Konversi V To F

Nilai tegangan merupakan nilai input yang diperoleh dari pengaturan tegangan dengan potensio meter, sedangkan pengukuran frekuensi diperoleh dari pengukuran sinyal keluaran DAC. Gambar 13 menunjukkan grafik pengujian tegangan masulkan dan frekuensi keluaran DAC. Rangkaian Volt/Hertz yang terdiri dari IC LM 331 dan IC4520 menghasilkan 8 data pulsa persegi sebagai masukan mikrokontrol ditunjukkan pada Gambar 14.

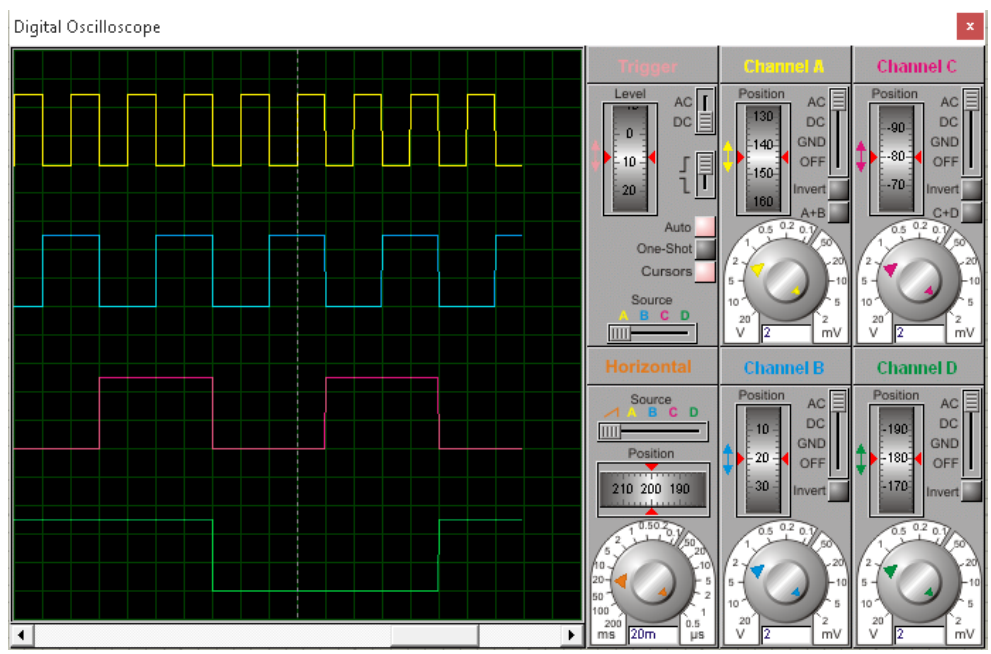

Gambar 14. Pengujian Pulsa Input Pembangkit Referensi 3 Fasa

Gambar 14 menunjukkan pulsa yang dihasilkan oleh IC 4520. IC 4520 menghasilkan 8 data pulsa input yang frekuensinya diatur menggunakan IC LM 331 sebagai data input mikrokontrol AT89S52. Dengan memasukkan data program pada IC AT89S52 kesalah satu PORT sebagi input maka akan menghasilkan output pada tiga PORT lainnya. PORT keluaran IC ini menghasilkan sinyal diskrit sejumlah 256 data yang diperbaiki melalui DAC 0800 sehingga membentuk gelombang sinus yang frekuensi dan amplitudonya dapat dikendalikan seperti pada gambar 15 .

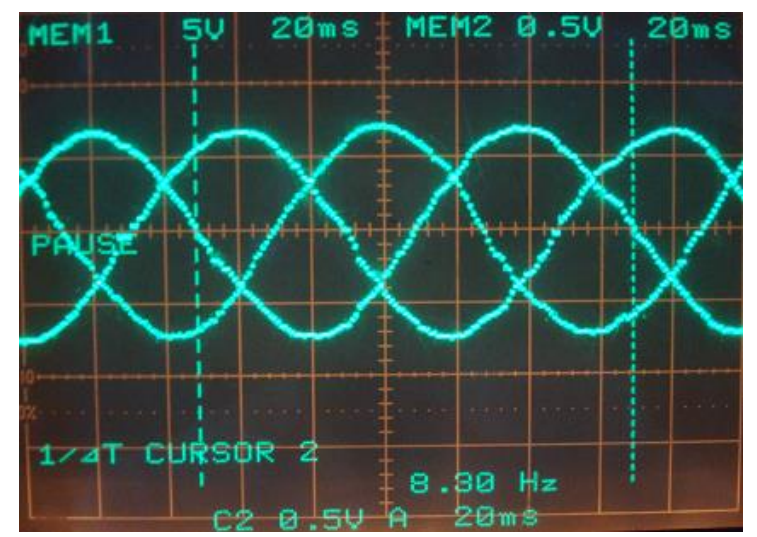

Gambar 15. Sinyal Sinusoidal Keluaran Mikrokontroller AT89S52 
Gambar 15 menunjukkan hasil pengukuran gelombang referensi yang dihasilkan melalui pemrograman pada mikrokontrol AT89S52 yang sudah di lewatkan pada DAC 0800. Keluaran DAC 0800 menghasilkan gelombang sinus murni sebagai sinyal referensi rangkaian kontrol Variable Speed Variable Voltage (VVVF) yang dirancang ini. Titik titik pengukuran pada rangkaian kontrol yaitu :

a. Tegangan DC pada input rangkaian $\mathrm{V}$ to $\mathrm{F}$

b. Frekuensi sinusoidal pada output DAC dan

c. Tegangan sinusoidal pada output DAC.

Adapun data pengujian rangkaian kontrol ditunjukkan pada Tabel 2:

Tabel 2 Pengujian rangkaian kontrol VVVF

\begin{tabular}{ccc}
\hline Input $\boldsymbol{Y}$ & \multicolumn{2}{c}{ Sinyal Keluaran } \\
Volt $\boldsymbol{D C}$ & Freq $(\boldsymbol{H z})$ & Sinusoidal $($ Vp $)$ \\
\hline 0,49 & 8,02 & 0,3 \\
1 & 8,65 & 0,745 \\
1,49 & 9,84 & 1,16 \\
2,06 & 11,24 & 1,62 \\
2,5 & 13,64 & 1,91 \\
3 & 16,34 & 2,21 \\
3,57 & 19,4 & 2,73 \\
4,01 & 21,75 & 3,1 \\
4,5 & 24,46 & 3,41 \\
5,06 & 27,03 & 3,9 \\
5,51 & 29,93 & 4,18 \\
6,07 & 32,94 & 4,59 \\
6,49 & 35,21 & 4,93 \\
7,08 & 38,35 & 5,25 \\
7,5 & 40,75 & 5,67 \\
8 & 43,54 & 6,18 \\
8,5 & 46,39 & 6,41 \\
9,06 & 50,45 & 6,86 \\
\hline
\end{tabular}

Tabel 2 menunjukkan perubahan tegangan DC input diikuti oleh perubahan tegangan keluaran dan frekuensi yang dihasilkan pada rangkaian kontrol VVVF.

\subsection{Pengujian Rangkaian Daya}

Indeks modulasi merupakan perbandingan amplitudo sinyal referensi dengan sinyal carrier berupa segitiga $5000 \mathrm{~Hz}$. Indeks modulasi menentukan tegangan keluaran inverter, yang digunakan untuk mengatur kecepatan motor induksi yang dikendalikan dengan inverter ini. Data pengujian inverter 3 fasa sebagai pengendali motor induksi 3 fasa dengan metode VVVF ditunjukkan pada tabel 3. 
Tabel 3. Pengujian inverter 3 fasa tanpa beban

\begin{tabular}{cccc}
\hline $\begin{array}{c}\text { Indeks } \\
\text { Modulasi }\end{array}$ & $\begin{array}{c}\text { Frekuensi } \\
(\boldsymbol{H z})\end{array}$ & $\begin{array}{c}\text { Tegangan } \boldsymbol{F}-\boldsymbol{F} \\
(\text { Volt })\end{array}$ & $\begin{array}{c}\text { Tegangan } \boldsymbol{F}-\boldsymbol{N} \\
(\text { Volt })\end{array}$ \\
\hline 0,04 & 8,02 & 0 & 0 \\
0,08 & 8,65 & 17 & 9 \\
0,17 & 9,84 & 29 & 17,6 \\
0,21 & 13,64 & 60 & 34,2 \\
0,32 & 16,34 & 72 & 40,8 \\
0,44 & 21,75 & 95 & 55,3 \\
0,50 & 24,46 & 105 & 60,7 \\
0,55 & 27,03 & 113 & 64,9 \\
0,61 & 29,93 & 121,5 & 69,4 \\
0,67 & 32,94 & 131 & 76,1 \\
0,72 & 35,21 & 137 & 78,8 \\
0,77 & 38,35 & 145 & 83,2 \\
0,83 & 40,75 & 155 & 87,2 \\
0,90 & 43,54 & 163 & 90,7 \\
0,93 & 46,39 & 166 & 94,2 \\
1,00 & 50,45 & 167 & 95,9 \\
\hline
\end{tabular}

Tabel 3 menunjukkan data pengukuran inverter 3 fasa tanpa beban. Pengujian pada rangkaian daya inverter ini menggunakan tegangan sumber AC 220 volt yang disearahkan menjadi tegangan DC 1 fasa dan diubah kembali menjadi tegangan AC 3 fasa seperti pada data pengukuran.

\section{KESIMPULAN}

a. Variable speed Drive dapat diimplementasikan dengan menggunakan IC LM 331 maka dapat dirancang rangkaian Voltage to Frekuensi yang sangat linier, hal ini menjadi terobosan dalam perancangan Variable Speed Drive (VSD) inverter yang memerlukan perubahan frekuensi dan tegangan secara bersamaan

b. Sinyal referensi 3 fasa selama ini didapatkan dengan menggunakan gelombang jala-jala 3 fasa yang di step down, dengan menggunakan algoritma pemrograman yang tepat pada mikrokntrol dapat diciptakan gelombang 3 fasa sesuai dengan jala-jala PLN.

c. Variable Speed Drive dengan mengunakan Volt/Hertz control menghasilkan tegangan keluaran sinus 3 fasa yang frekuensi dan tegangannya berubah secara bersamaan. Berdasar data pengujian perubahan tegangan dan frekuensi terjadi secara linier dengan dengan rasio $1: 5,2$.

d. Perubahan indexs modulasi menghasilkan perubahan tegangan keluaran inverter yaitu pada pengujian tegangan fasa-netral dan tegangan antar fasa. Perbandingan tegangan fasa netral dan tegangan antar fasa menunjukkan nilai perbandingan $1: 1,733$ atau $1: \sqrt{3}$.

\section{DAFTAR PUSTAKA}

[1] SZABÓ C, Maria IMECS, Ioan Iov, 2006, INCZE, VOLT-HERTZ CONTROL OF THE SYNCHRONOUS MOTOR WITH RAMP EXCITING VOLTAGE, Annals of the University of Craiova, Electrical Engineering series, No. 30.

[2] Trzynadlowsky Andrzej M, 2001, "Control of Induction Motors", department of electrical engineering university of Nevada.

[3] Akhmad Musafa, 2007, Simulasi Pengendalian Kecepatan Motor Induksi tiga Fasa tanpa Sensor Kecepatan, Program Studi Teknik Elektro Fakultas Teknik-Universitas Budi Luhur.

[4] Supari, 2001, Kendali Tegangan Motor Induksi untuk Penghematan Energi Berbasis Mikrokontroler, T E-UGM, Yogyakarta.

[5] Kelvin Lye kwong Loong., Nik ramzi bin Idris, 2008, Microcontroller Based Space Vector Modulation (SVM) Signal Generator, Faculty of Electrical Engineering UTM.

[6] Texas Instruments Incorporated, 2015, LMx31x Precision Voltage-to-Frequency Converters, SNOSBI2C, Dallas, Texas, United States.

[7] Atmel Corporation, , 2001, AT89S52 8-bit Microcontroller with 4K Bytes In-System Programmable Flash, San Jose, California, United States.

[8] Riyadi, Slamet, 2010, "Penggerak Kecepatan Variable Pada Motor Induksi Tiga Fasa Berbasis $\mathrm{V} / \mathrm{Hz}$ dan Direct Torque Control ", Unika Soegijapranata. 
Jurnal SIMETRIS, Vol. 9 No. 1 April 2018

ISSN: 2252-4983

[9] EXAR Corporation, 2008, XR 2206 Monolithic Function Generator, 48720 Kato Road, Fremont, United States 